\title{
Views on Interactive E-Book Use in Science Education of Teachers and Students Who Perform E-book Applications ${ }^{12}$
}

\author{
Ümmühan Ormanc1 ${ }^{3}$, Salih Çepni ${ }^{4}$
}

\begin{abstract}
In parallel with the development in information and communication technologies, technology integration has been initiated in science education programs and lesson environments, and educational e-contents have been created by National Education and related institutions by making the books compatible with technology supported education. In parallel with this situation, the aim of the study was to obtain the interactive e-book views of the teachers and students performing the applications. This research, conducted in accordance with the case study, was carried out with three teachers working in three different secondary schools in Bursa and 71 students studying in their classrooms. Interactive e-book prepared in HTML format was developed by the researcher. The student opinion form, student interview form and teacher interview form were used as data collection tools. The data obtained were analyzed in accordance with the content and descriptive analysis. In the findings obtained from the teachers, it was understood that the teachers liked the interactive e-book and found it useful. The main reason for this is thought to be that the interactive e-book was prepared as a progressive system in line with the regular, systematic and curriculum objectives. In addition, students stated that they liked the interactive e-book and found it beautiful. In this context, it can be said that similar interactive e-book examples can be created in different science subjects.
\end{abstract}

Keywords: Interactive e-book, view, secondary school student, science teacher, science education.

\footnotetext{
${ }^{1}$ This study is part of the first author's doctoral dissertation.

${ }^{2}$ Research permit numbered 86896125-605.01-E.9113990 was obtained within the scope of the study.

${ }^{3}$ Asst. Prof. Dr., Bursa Uludağ University, Faculty of Education, Department of Educational Sciences, ummuhan45@gmail.com, https://orcid.org/0000-0003-3669-4537.

${ }^{4}$ Prof. Dr., Bursa Uludağ University, Faculty of Education, Department of Mathematics and Science Education, cepnisalih@yahoo.com, https://orcid.org/0000-0003-2343-8796.

Received: 23.05.2019, Accepted: 29.04.2020
} 


\title{
Uygulamaları Gerçekleştiren Öğretmen ve Öğrencilerin Fen Eğitiminde Etkileşimli E- Kitap Kullanımına İlişkin Görüşleri
}

\begin{abstract}
$\ddot{O} z$
Bilişim ve iletişim teknolojilerinde gelişime paralel olarak fen bilimleri öğretim programlarına ve ders ortamlarına teknoloji entegrasyonu yapılmaya başlanmış ve kitapların teknoloji destekli öğretime uyumlu hale getirilerek Milli Eğitim ve ilgili kuruluşlar tarafından eğitsel e-içerikler oluşturulmaya başlanmıştır. Bu duruma paralel olarak yapılan çalışmada, uygulamaları gerçekleştiren öğretmen ve öğrencilerin etkileşimli e-kitaba ilişkin görüşlerinin alınması amaçlanmıştır. Durum çalışmasına uygun olarak gerçekleştirilen bu araştırma, Bursa ilindeki üç farklı ortaokulda görev yapan üç öğretmen ve onların sınıflarında öğrenim gören 71 öğrenci ile sürdürülmüştür. Çalışmada HTML formatında hazırlanan etkileşimli e-kitap araştırmacı tarfından geliştirilmiştir. Veri toplama aracı olarak öğrenci görüş formu, öğrenci görüşme formu ve öğretmen görüşme formu kullanılmıştır. Elde edilen veriler içerik ve betimsel analize uygun olarak analiz edilmiştir. Öğretmenlerden elde edilen bulgularda; etkileşimli e-kitabın öğretmenler tarafindan beğenildiği, faydalı bulunduğu anlaşılmıştır. Bu durumun temel nedeninin; etkileşimli e-kitabın düzenli, sistemli ve kazanımlara paralel olarak aşamalı bir sistem şeklinde hazırlanmasından kaynaklandığı düşünülmektedir. Bununla birlikte yapılan çalışmada öğrencilerin etkileşimli e-kitabı beğendikleri ve güzel bulduklar ifade etmişlerdir. Bu bağlamda farklı fen konularında benzer etkileşimli e-kitap örneklerinin oluşturulabileği söylenebilir.
\end{abstract}

Anahtar Sözcükler: Etkileşimli e-kitap, görüş, ortaokul öğencisi, fen bilimleri öğretmeni, fen eğitimi. 


\section{Introduction}

In parallel with the rapid increase in information and the development in technology, there have been changes in the features that individuals should have. Turkish Industry and Business Association (TUSIAD) (2017) in particular, stated that Turkey needs to create a workforce that is creative, innovative, interdisciplinary thinking and has the necessary skills in technology and digitization by providing a strong STEM infrastructure to its young population in order to realize its potential. Similarly, in Science Education, individuals are expected to be inquiring, critical thinking, problem-solving and decision-making skills, lifelong learners, and have the science-related skills, attitudes, values and understandings necessary to understand nature (Çepni \& Çil, 2009). At this point, learners need to be equipped with 21 st century skills for their future academic, professional and personal success, and to this end, the development of information and communication technologies (ICT) literacy becomes an important function of educational institutions (Doğan, Murat \& Seferoğlu, 2016).

In parallel with the developments in information and communication technologies, technology integration has gained importance in teaching environments. It can be said that one of them is the science course, technology integration is done to the course environments and books are started to be adapted to technology-supported teaching. At this point, the creation of e-content, e-books and especially e-books compatible with the program in science education has become important for the literature. Interactive e-books, unlike e-books, contain multimedia objects (audio, video, animation) and interaction (such as touch, drag). Interaction is seen as the center of an educational experience and is positioned as the main focus of online learning (Garrison \& Cleveland-Innes, 2005). In this way, content and books will be enriched and students' participation in classes will be increased in parallel with their interest in technology. As stated by Bozkurt (2013), interactive e-books have started to attract attention due to the flexible and easy use of the content with its enriched environment options and easy-to-use presentation and access options.

It is thought that there is a need to discover new ways to support new digital technologies such as interactive e-books and e-contents (Barate, Ludovico \& Mangione, 2014). In this context, while developing an interactive e-book has an important place in the field, it can be said that 
there is a lack of interactive science teaching material for technology integration in our country. At this point, when we look at the studies on interactive e-books in the literature, it can be said that studies on the subject have started (Baughman, Ehmann \& Vilcheck, 2013; Erdoğdu, 2016; Erişti, Uluuysal \& Dindar, 2013; Gebya Oktammeria \& Novita, 2012; Hakkari, Yeloğlu, Tüysüz \& İlhan, 2017; Laili \& Novita, 2014; O’Mahony, 2014; Önder \& S1lay, 2016; Soga, Nakahara, Kawana, Fuse \& Nakamur, 2015; Tania \& Fadiawati, 2015). However, many of the studies on interactive e-books are theoretical. In this context, it can be said that interactive ebook applications are carried out and studies are needed to obtain teacher and student opinions.

In the study, while developing interactive e-book, it was aimed to use both ICT tools such as interactive board and animation and to use the inquiry based learning approach suggested by the program. As the guided inquiry method is recommended at the sixth grade level, this was taken into account in the study. Inquiry-based learning is used in teaching programs and can be included in an interactive e-book. It is thought that it will contribute to the students in terms of involving the situations related to daily life in inquiry, finding and solving the existing problems by themselves, and using the skills required in addition to the knowledge in this process. The inquiry approach is a recommended approach to use in our country, and with the development of technology, the importance given to web-supported materials is increasing. In this study, a guided inquiry approach enriched with an interactive e-book enriched with information and communication technologies such as interactive board, Animation, animated concept caricature, and an interactive e-book were created. In this context, it is aimed to obtain the interactive e-book views of the teachers and students performing the applications.

\section{Conceptual Framework}

The addition of multimedia features such as video, audio, animation, game, and animated command to e-books has enabled interactive e-books to be more preferable than printed interactive books (Kara \& Keş, 2016). New generation smartphones, tablet computers and other mobile devices have already opened the way for the development of interactive e-books with their powerful hardware features (Bozkurt \& Bozkaya, 2013a). Similarly, it is aimed to turn the books used by the Ministry of National Education into enriched books (interactive e-books), to design interactive videos and course materials under the name of e-content and to share them from the website to be established (MoNE, 2010). In this context, all these developments began to necessitate the conversion of books into interactive e-books. The visual of the book, e-book 
and interactive e-book interactions with the user is given in Figure 1. When the figure is analyzed, it is understood that the interaction and diversity increased from the traditional book to the interactive e-book.
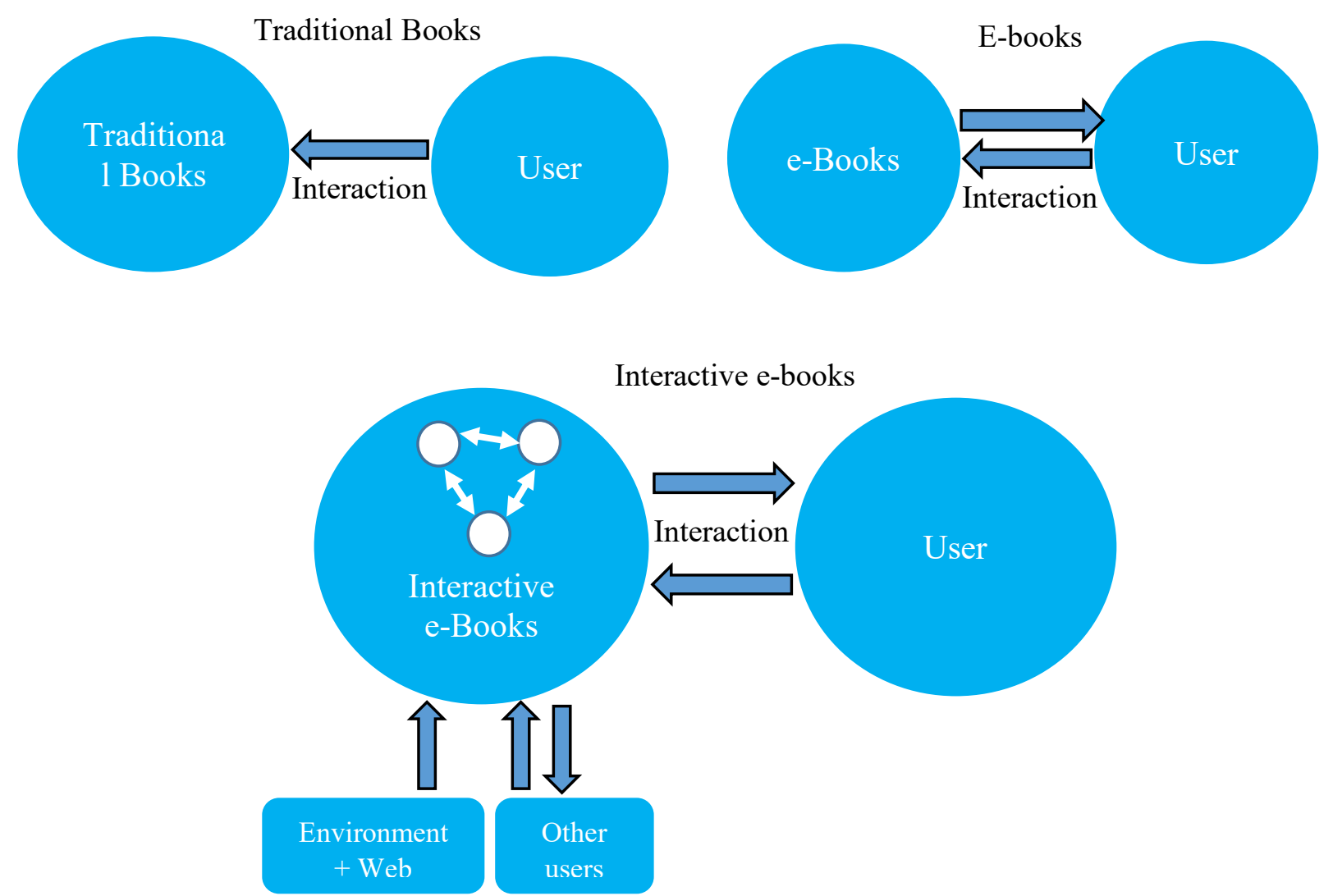

Figure 1. Book, e-book and interactive e-book interactions with the user (Bozkurt \& Bozkaya, 2013b)

Enriched e-book, also known as interactive digital book is a digital version of the book (printed or e-book) digitally equipped with various elements such as videos, photographs, animations, mini-tests, maps and special symbols (Arslan, 2014). In other words, interactive e-books (iBook) are e-books enriched with various features where interactive experiences such as audio narration, embedded media and hyperlinks are presented to the user (Belveal, 2016). Interactive e-books are a type of e-books that contain and support multimedia content (Alfrijat, AlMsie'deen \& Alhalhouli, 2010). With these added multimedia objects, books turn into interactive e-books (Gümüş, Güler, Güler \& Erorta, 2012). Text, audio video, image, figure, table, chart, graphic, model, dictionary, self-assessment studies, surveys, activities, research activities, problem situations, reviews, concept map, presentation files, demonstration, videos and similar resources, digital sources (Gasouka, Kapaniaris, Arvanitidou, Foulidi \& Raptou, 
2013). In this context, it can be stated that multimedia objects have an important place in interactive e-books. In addition, another important feature of interactive e-books is that it contains interaction. The ability of the student to perform actions such as selecting, marking, changing, stopping by touching the interactive e-book, in other words, interfering with the content makes these books more attractive (Özer \& Türel, 2015). As Phadung (2015) states, the design principles of the interactive e-book include multimedia (image, animation, video etc.), interaction and learning design.

The widespread use of mobile devices and the internet has also changed the e-book approach (Özoğlu, Kaysi \& Özoğlu, 2014). In other words, many applications or programs started to be used in the interactive e-book development process. According to Gümüş et al. (2012), common e-book formats are "(.pdf) - PDF (Portable Document Format) - Adobe", "(.djvu) DjVu - AT\&T Lab.”, “(.Epub) - ePub (Electronic Publication) - International Digital Publishing Forum (IDPF) ",“ (.prc, .mobi) - Mobipocket ”,“ (.azw) - Kindle - Amazon ”,“ iBook- Apple ”,“ Microsoft LIT - Microsoft ” Are "(.txt) - Platin text", "(.html) - HTML". In this context, many applications are used in the development of interactive e-books, and HTML is among them. Especially HTML5 web technology is adopted in e-books in order to meet the need for multimedia and rich user interaction (Choi, Lee \& Kim, 2014). In this study, all these applications were examined, and HTML format was preferred because of the large size of the material and to increase its sustainability.

The approach based on interactive e-book is inquiry-based learning, which is also included in science curricula. Inquiry-based learning can be expressed as the whole of the knowledge, skills and attitudes that individuals acquire while having questions about the world and answering the questions with scientific studies (Karakuyu, Bilgin \& Drive, 2013; K1zılaslan, Sözbilir \& Yaşar, 2012). In guided inquiry used in the study, the teacher only gives the problem and materials to be investigated, and the students follow their own procedures to solve the problem (Colburn, 2000; Colburn, 2004; Nivalainen, Asikainen \& Hirvonen, 2013). In the study, guided inquiry based learning approach is based on interactive e-books and different teaching techniques are used to enrich. In this study, it was tried to enrich the interactive e-book by using experimental learning, web supported learning, animations, animated concept cartoons and interactive whiteboard by considering the content and scope of the unit. Experiment method is the way students learn by researching teaching subjects in laboratories or private classrooms, individually or in groups, such as observation, experiment, hands-on learning (Karakuş, 2006). 
Parallel to the experiments and activities taking place in science education, the use of experiments was deemed appropriate. Another technique is concept cartoons. Concept cartoons include discussions about a scientific concept from a daily situation or daily life in a particular branch of science (Steininger \& Lembens, 2012; Stephenson \& Warwick, 2002). In line with the fact that the discussion environment has an important place in research-based learning, the use of concept cartoons has been deemed appropriate. It has been deemed appropriate to turn concept cartoons into animated concept cartoons in order to provide technology support and to be used more effectively. In addition, the animation used in the study can be defined as moving pictures that depict the movement of drawn objects (Mayer \& Moreno, 2002). In parallel with the whole process taking place on HTML, it can be stated that it is web supported learning. Web-assisted learning is a hypermedia-based curriculum that uses www's attributes and resources to create a meaningful learning environment in which learning is supported (Khan, 1997). In addition, interactive whiteboards, which have gained importance in recent years with their interaction feature, are also included in the enrichment process. Interactive whiteboard is a large touch screen electronic board that works by establishing a computer and projection connection (Akbaş \& Pektaş, 2011; Campbell \& Martin, 2010). In this context, enrichment was provided with both teaching methods and ICT tools, and the structure of the interactive e-book sample was tried to be created.

\section{Methodology}

In this study, the case study was used as it was aimed to apply the interactive e-book sample and to get the opinions of the students and teachers regarding this process. Case study is a method that explains the very fine details of an event, person or group, and the interrelationships of cause-effect and variables (Çepni, 2018). In the research, it was thought to be suitable for the case study since a situation was determined and a deep understanding was provided.

\section{Study Group}

The study group consists of three teachers working in three different secondary schools in Bursa and their classes. Research permit numbered 86896125-605.01-E.9113990 was obtained 
within the scope of the study. While choosing schools in the study, the physical conditions of the schools have been taken into account as interactive e-books will be implemented and interactive board and internet connection are needed in the process. Purposeful sampling was chosen in this study. Three teachers participated in the study, teacher A has about 10 years of experience, teacher $\mathrm{B}$ has about 20 years of experience, and teacher $\mathrm{C}$ has about 30 years of experience. Before starting the study, teachers were observed for a certain period of time and course processing processes were recorded with the help of an observation form. The teaching features of teachers are classified based on the data obtained from observations. Teacher $\mathrm{A}$ is a teacher who tries to use laboratory and active learning approaches effectively in her lessons. Teacher B, on the other hand, uses the science laboratory even though it is not very active, pays attention to the use of computers and interactive boards. Teacher $\mathrm{C}$ occasionally takes place in active learning approaches and use of technology, and continues her classes in accordance with a more classical understanding. However, all teachers are willing to continue their lessons through interactive e-books. When we look at the students participating in the study, a total of 71 sixth grade students, 22 from secondary school A, 26 from secondary school B, 23 from secondary school C participated. 33 of the students are female and 38 are male.

\section{Data Collection Tools}

In the study, opinion questionnaire and semi-structured interviews were used to get student opinions, while semi-structured interviews were used to get teacher opinions.

Student opinion survey: In the study, opinion questionnaire was used in order to obtain student opinions on web-supported science material in accordance with the guided inquiry approach. At this point, it was decided that the opinion questionnaire consisting of open-ended questions was appropriate since it was difficult to analyze the questions by applying semi-structured interview questions to all of the students in the study and to reach the opinions of all students. While creating the opinion questionnaire in the study, first of all the questions were formed in parallel with the main purpose. It was then submitted to the expert's opinion for content and facial validity. As a result of the examinations of two experts in the field of science education, the opinion survey was finalized in parallel with the suggestions and corrections. However, for the comprehensibility of the questionnaire, it was checked by a person with a feature parallel to the study group and its understandability was checked. Opinion questionnaire focused on students' opinions about the material developed, the effects of the material, pros and cons. 
Student interview form: In addition to the opinion questionnaire, a semi-structured interview form was also used to obtain student views. In the development of the form, a process similar to the opinion form has taken place. Semi-structured interviews were conducted with 25 students, including nine from secondary school a, eight from secondary school B, and eight from secondary school C. When selecting students, consideration was given to the selection of students who are at different levels in terms of their demographics, science achievement and participation in the course, taking into consideration the basis of volunteerism. Interviews were conducted separately with each student and each interview was recorded with a voice recorder. The names of the students interviewed were kept secret and the students were named with codes such as SA1 (Student A school 1), SA2 (Student A school 2), SB1 (Student B School 1), SC1 (Student C school 1)...

Teacher interview form: In the study, semi-structured interviews were used to obtain teachers' opinions on the use of web-supported science material in accordance with the guided inquiry approach. While preparing the semi-structured interview form, first of all the studies in the literature were examined and the first questions were given. The questions were then examined by two science education experts and the questions were analyzed in terms of content and face validity. Experts stated that a question should be added about what the teachers liked and disliked on the website, and sub-questions such as cognitive effects and affective effects of the method should be added to the questions related to the effects. As a result of the arrangements, the final form of the form was given. Semi-structured interviews were conducted with three teachers after the applications. One of the teachers is woman and two are men. Interviews were conducted individually with each teacher and recorded in sound. Then, the interviews were listened one by one and transcribed. The names of the teachers interviewed were kept secret and the teachers were coded as A, B and C.

\section{Material Development Process}

In this study, interactive e-book was prepared by the researcher in HTML format. The content of the interactive e-book was developed in accordance with the web-supported guided inquiry approach. The guided inquiry approach used the steps of the research cycle developed by Llewellyn (2014). The process started with a research question in the first step, the inquiry step. In this process, animated concept cartoons, an event or animations from daily life were used. 
In this context, it can be stated that multimedia objects are frequently used in the query step. In the section of revealing the existing information, which is the second step, brainstorming and open-ended questions were used to examine the students' prior knowledge. Students were asked to establish a prediction sentence or hypothesis to find an answer to the research question during the prediction. Since the guided inquiry approach was used in planning and making the application, the teacher planned the activity, prepared the objectives and materials. Then, students were asked to perform the experiments or activities sometimes individually and sometimes as a group. However, some experiments and activities were carried out as a demonstration experiment due to lack of material. At this stage, the material or process is supported by multimedia objects. In the next step, commenting, students were asked to analyze their observations and data and come to a conclusion. In this section, students can make the necessary calls using the Internet. In the presentation of the results, the students share their findings and information in the classroom. In this part, theoretical information is given as the course is summarized. Then, evaluation activities were initiated. In this process, multimedia objects (audio, video, visual animations, simulations, etc.) are integrated into all steps where necessary. In this context, it can be stated that the interactive e-book contains both multimedia objects and includes interactive features. The material was applied by the teachers throughout the sixth grade "Systems in Our Body" unit in middle school. Some images related to the material are given in Figure 2 and the entire material can be accessed at http://www.ummuhanormanci.com/zkitap/. 

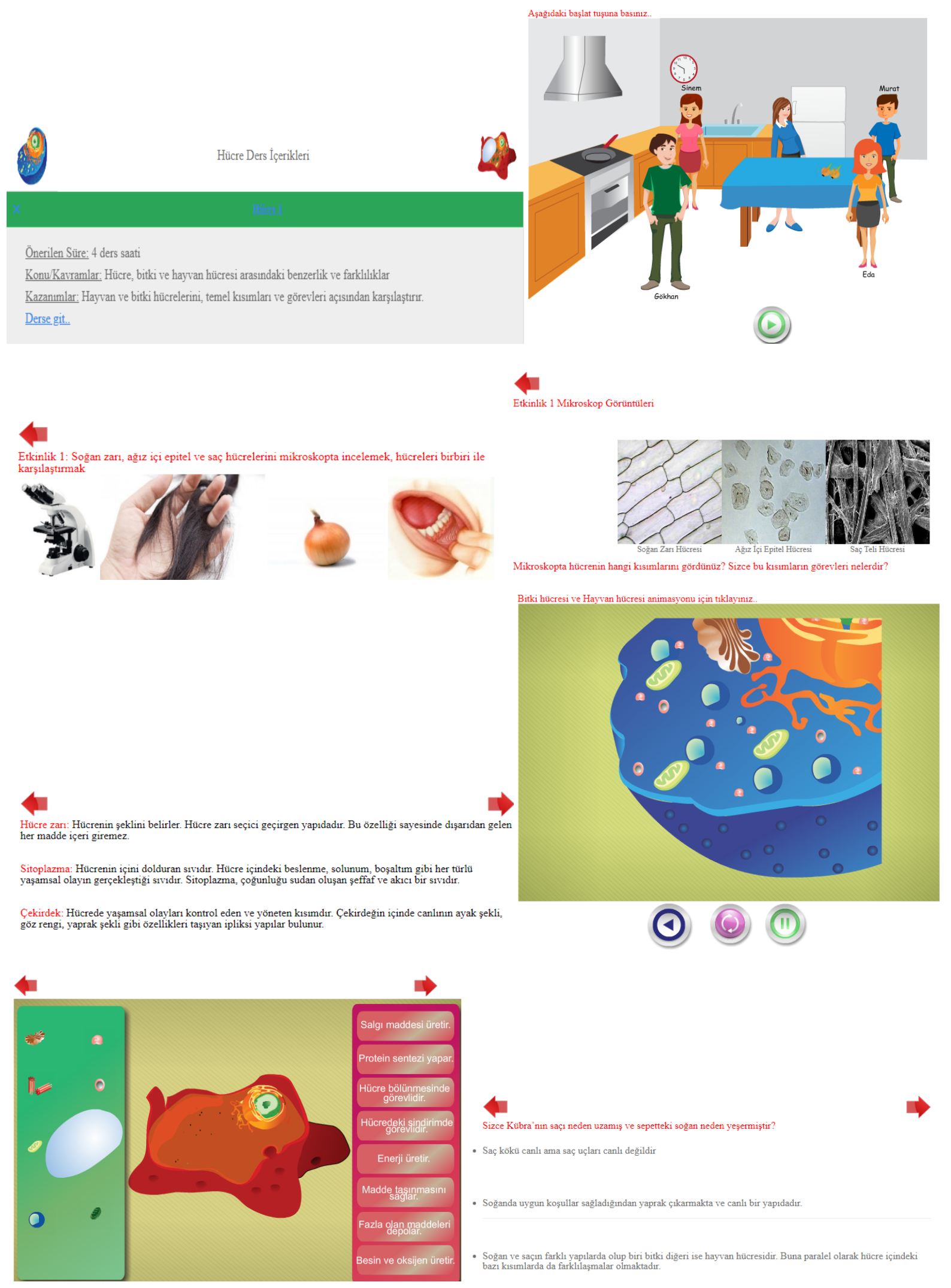

Figure 2. Examples of interactive e-book pages 


\section{Data Analysis}

While the data obtained from the opinion questionnaire was analyzed with content analysis for the students, some of the data obtained from the interviews were used to support content analysis and some were used to support the data obtained from the opinion survey. The data obtained from teacher interviews were subjected to descriptive analysis.

\section{Findings}

In the study, student opinion questionnaire and student interviews were used to determine student views regarding the interactive e-book. Teacher interviews were used to determine teachers' opinions. In the study, findings regarding the opinions of students and teachers about the material are given separately.

\section{Findings Regarding Students' Opinions About Interactive E-Books}

In the data obtained from the opinion survey, the opinions of the students about the teaching of the "systems in our body" unit on the website are given in Table 1.

Table 1

Students' Views on Teaching the Course Through the Interactive E-Book

\begin{tabular}{|c|c|c|c|c|c|}
\hline Category & Code & $\mathrm{f}$ & $\%$ & $\mathrm{f}$ & $\%$ \\
\hline \multirow{9}{*}{$\begin{array}{l}\text { Features of the } \\
\text { material }\end{array}$} & Having a good website & 21 & 21.0 & \multirow{9}{*}{57} & \multirow{9}{*}{57.0} \\
\hline & Being beautiful & 14 & 14.0 & & \\
\hline & Using interactive boards & 7 & 7.0 & & \\
\hline & Being fun & 6 & 6.0 & & \\
\hline & Having animations & 3 & 3.0 & & \\
\hline & Having videos & 2 & 2.0 & & \\
\hline & Having educational / instructive content & 2 & 2.0 & & \\
\hline & Providing clearer information & 1 & 1.0 & & \\
\hline & Having pictures & 1 & 1.0 & & \\
\hline \multirow{9}{*}{$\begin{array}{l}\text { Learning } \\
\text { features }\end{array}$} & Providing better understanding & 17 & 17.0 & \multirow{9}{*}{38} & \multirow{9}{*}{38.0} \\
\hline & Assisting in lessons & 6 & 6.0 & & \\
\hline & Providing learning & 6 & 6.0 & & \\
\hline & Keeping in mind & 2 & 2.0 & & \\
\hline & Providing reinforcement & 2 & 2.0 & & \\
\hline & Having positive effects on learning & 2 & 2.0 & & \\
\hline & The process being more efficient & 1 & 1.0 & & \\
\hline & Providing benefiting from different sources & 1 & 1.0 & & \\
\hline & Being informative & 1 & 1.0 & & \\
\hline \multirow{3}{*}{$\begin{array}{l}\text { Negative } \\
\text { features }\end{array}$} & Having no effect & 2 & 2.0 & \multirow{3}{*}{5} & \multirow{3}{*}{5.0} \\
\hline & Not liking the website & 2 & 2.0 & & \\
\hline & Some points being insufficient & 1 & 1.0 & & \\
\hline Total & & 100 & 100.0 & 100 & 100.0 \\
\hline
\end{tabular}


As can be seen in Table 1, students' opinions about teaching lessons from the website were gathered in three categories: features of the material, learning features and negative features. The students stated that the interactive e-book prepared was $21.0 \%$ often a good website and $14.0 \%$ often a beautiful one. However, students stated that $17.0 \%$ of the interactive e-books provide better understanding, $6.0 \%$ of them said they assist in lessons and $6.0 \%$ of them stated that they provide learning. On the other hand, $2.0 \%$ of the the students stated that the interactive e-book had no effect and $2.0 \%$ of them did not like the website. In this context, it can be stated that students generally like the interactive e-book / website. In the interviews, this question has been examined in more detail and it has been tried to focus on the features that make up the material. Students' opinions about the properties of the material related to this situation are given in Table 2.

Table 2

Students' Opinions About Interactive Interactive E-Book Features

\begin{tabular}{|c|c|c|c|c|c|c|}
\hline Category & Sub-category & Code & $\mathrm{f}$ & $\%$ & $\mathrm{f}$ & $\%$ \\
\hline \multirow{16}{*}{ 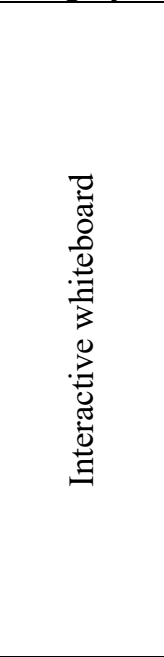 } & \multirow{7}{*}{ Individual effect } & Providing better understanding & 4 & 2.0 & \multirow{7}{*}{15} & \multirow{7}{*}{7.5} \\
\hline & & Being useful & 3 & 1.5 & & \\
\hline & & Providing support with visuals & 3 & 1.5 & & \\
\hline & & Increasing curiosity & 2 & 1.0 & & \\
\hline & & Being entertaining & 1 & 0.5 & & \\
\hline & & Motivating the lesson & 1 & 0.5 & & \\
\hline & & Being clear and understandable & 1 & 0.5 & & \\
\hline & \multirow{8}{*}{ Technically } & Being beautiful & 10 & 5.0 & \multirow{8}{*}{21} & \multirow{8}{*}{10.5} \\
\hline & & Preventing time loss & 2 & 1.0 & & \\
\hline & & No glare & 2 & 1.0 & & \\
\hline & & Being bigger & 2 & 1.0 & & \\
\hline & & Having a touchscreen & 2 & 1.0 & & \\
\hline & & Not requiring writing on the board & 1 & 0.5 & & \\
\hline & & Providing instant access to content & 1 & 0.5 & & \\
\hline & & Easy to enter & 1 & 0.5 & & \\
\hline & Negative & Being unnecessary & 1 & 0.5 & 1 & 0.5 \\
\hline \multirow{12}{*}{ 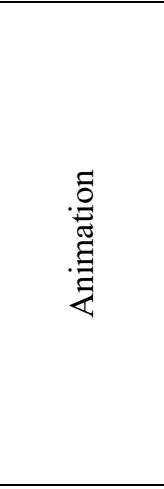 } & \multirow{7}{*}{ Cognitive } & Providing better understanding & 9 & 4.5 & \multirow{7}{*}{24} & \multirow{7}{*}{12.0} \\
\hline & & Being more real & 5 & 2.5 & & \\
\hline & & Being useful & 3 & 1.5 & & \\
\hline & & Providing detailed learning & 3 & 1.5 & & \\
\hline & & Providing to reinforce the subject & 2 & 1.0 & & \\
\hline & & Making the lesson more efficient & 1 & 0.5 & & \\
\hline & & Ensuring persistence & 1 & 0.5 & & \\
\hline & \multirow{5}{*}{ Affective } & Being beautiful & 6 & 3.0 & \multirow{5}{*}{20} & \multirow{5}{*}{10.0} \\
\hline & & Being good & 6 & 3.0 & & \\
\hline & & Being visual & 4 & 2.0 & & \\
\hline & & Having both audio and video & 2 & 1.0 & & \\
\hline & & Appro & 2 & 1.0 & & \\
\hline \multirow{3}{*}{ 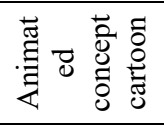 } & \multirow{3}{*}{ Affective } & Being beautiful & 13 & 6.5 & \multirow{3}{*}{25} & \multirow{3}{*}{12.5} \\
\hline & & Being good & 7 & 3.5 & & \\
\hline & & Being fun & 5 & 2.5 & & \\
\hline
\end{tabular}




\begin{tabular}{|c|c|c|c|c|c|c|}
\hline & \multirow{8}{*}{ Cognitive } & Providing understanding of true-false & 5 & 2.5 & \multirow{8}{*}{22} & \multirow{8}{*}{11.0} \\
\hline & & Being useful & 4 & 2.0 & & \\
\hline & & Providing understanding & 4 & 2.0 & & \\
\hline & & Being thought-provoking & 3 & 1.5 & & \\
\hline & & Providing pretending to be characters & 2 & 1.0 & & \\
\hline & & Enabling animation & 2 & 1.0 & & \\
\hline & & Being both fun and instructive & 1 & 0.5 & & \\
\hline & & Introduction to the topic & 1 & 0.5 & & \\
\hline \multirow{11}{*}{ 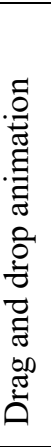 } & \multirow{4}{*}{ Affective } & Being beautiful & 11 & 5.5 & \multirow{4}{*}{21} & \multirow{4}{*}{10.5} \\
\hline & & Being fun & 5 & 2.5 & & \\
\hline & & Being good & 4 & 2.0 & & \\
\hline & & Being remarkable & 1 & 0.5 & & \\
\hline & \multirow{7}{*}{ Cognitive } & Testing if we understand the issue & 7 & 3.5 & \multirow{7}{*}{18} & \multirow{7}{*}{9.0} \\
\hline & & Contributing to learning & 3 & 1.5 & & \\
\hline & & Enabling to see shapes / places & 3 & 1.5 & & \\
\hline & & Being informative & 2 & 1.0 & & \\
\hline & & Enabling to use interactive board & 1 & 0.5 & & \\
\hline & & Ensuring participation & 1 & 0.5 & & \\
\hline & & Enabling animation & 1 & 0.5 & & \\
\hline \multirow{11}{*}{ 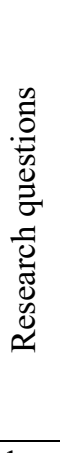 } & \multirow{8}{*}{ Cognitive } & Provides better understanding & 5 & 2.5 & \multirow{8}{*}{23} & \multirow{8}{*}{11.5} \\
\hline & & Introducing the topic & 5 & 2.5 & & \\
\hline & & Providing information & 4 & 2.0 & & \\
\hline & & Being thought-provoking & 3 & 1.5 & & \\
\hline & & Improving forecasting & 3 & 1.5 & & \\
\hline & & Making sure to listen to the lesson & 1 & 0.5 & & \\
\hline & & Providing discovery & 1 & 0.5 & & \\
\hline & & Ensuring participation & 1 & 0.5 & & \\
\hline & \multirow{3}{*}{ Affective } & Being good & 6 & 3.0 & \multirow{3}{*}{10} & \multirow{3}{*}{5.0} \\
\hline & & Being beautiful & 2 & 1.0 & & \\
\hline & & Being interesting & 2 & 1.0 & & \\
\hline & & & 200 & 100.0 & 200 & 100.0 \\
\hline
\end{tabular}

As can be seen in Table 2, the students interviewed gave opinions about interactive board, animation, animated concept cartoon, drag and drop animations and research questions. The students stated that the interactive board is $5.0 \%$ often beautiful and $2.0 \%$ often provides better understanding. Regarding the animations, students reported that they $4.5 \%$ often provided better understanding, $2.5 \%$ often more real, $3.0 \%$ often beautiful, and $3.0 \%$ often good. In animated concept cartoons, students stated that they are $6.5 \%$ often beautiful and $2.5 \%$ often provided understanding of true or false. Drag-and-drop animations have been expressed by students that $5.5 \%$ are often beautiful and $3.5 \%$ often helps to test whether they understand the subject. Finally, it was stated that the research questions used during the process were effective in providing $2.5 \%$ more comprehension, $2.5 \%$ frequently in introducing the topic and $3.0 \%$ frequently. In this context, it was understood that the interactive e-book and its features were emphasized by the students and many positive opinions were expressed about their contributions on the students. In the study, opinions about the contributions of the application on the students are given in Table 3. 
Table 3

Opinions of the Students About the Contributions of the Interactive E-Book

\begin{tabular}{|c|c|c|c|c|c|}
\hline Category & Code & $\mathrm{f}$ & $\%$ & $\mathrm{f}$ & $\%$ \\
\hline \multirow{4}{*}{ Effect in terms of skill } & $\begin{array}{l}\text { Being able to establish relationship between } \\
\text { topics }\end{array}$ & 11 & 8.5 & \multirow{4}{*}{17} & \multirow{4}{*}{13.2} \\
\hline & Reflecting on daily life & 3 & 2.3 & & \\
\hline & Understanding your friends better & 2 & 1.6 & & \\
\hline & Doing group work & 1 & 0.8 & & \\
\hline \multirow{2}{*}{$\begin{array}{l}\text { Contribution to the } \\
\text { emotional domain }\end{array}$} & Being more fun & 4 & 3.1 & \multirow[b]{2}{*}{6} & \multirow[b]{2}{*}{4.7} \\
\hline & Being beautiful & 2 & 1.6 & & \\
\hline \multirow{13}{*}{$\begin{array}{l}\text { Effect on cognitive } \\
\text { domain }\end{array}$} & Providing better understanding & 23 & 17.8 & \multirow{13}{*}{70} & \multirow{13}{*}{54.3} \\
\hline & Providing better learning & 15 & 11.6 & & \\
\hline & Reinforcing what has been learned & 7 & 5.4 & & \\
\hline & Ensuring permanent learning & 6 & 4.7 & & \\
\hline & Contains different / many examples & 4 & 3.1 & & \\
\hline & Learning detailed information & 4 & 3.1 & & \\
\hline & Providing easy learning & 2 & 1.6 & & \\
\hline & Being useful & 2 & 1.6 & & \\
\hline & Being more efficient & 2 & 1.6 & & \\
\hline & Repetition & 2 & 1.6 & & \\
\hline & Providing answers to questions & 1 & 0.8 & & \\
\hline & Providing research & 1 & 0.8 & & \\
\hline & Getting new information & 1 & 0.8 & & \\
\hline \multirow{9}{*}{$\begin{array}{l}\text { Effect in terms of } \\
\text { technology }\end{array}$} & Providing visuality & 8 & 6.2 & \multirow{9}{*}{36} & \multirow{9}{*}{27.9} \\
\hline & Ability to use the website & 7 & 5.4 & & \\
\hline & Enabling to use interactive whiteboard & 5 & 3.9 & & \\
\hline & Providing seeing live & 4 & 3.1 & & \\
\hline & Providing better understanding with videos & 4 & 3.1 & & \\
\hline & Animations having a positive effect & 3 & 2.3 & & \\
\hline & Ability to use the Internet & 2 & 1.6 & & \\
\hline & Containing sound & 2 & 1.6 & & \\
\hline & Offering an active environment & 1 & 0.8 & & \\
\hline Total & & 129 & 100.0 & 129 & 100.0 \\
\hline
\end{tabular}

As can be seen in Table 3, the responses of the students to the opinion survey were collected in four categories: the effect of the interactive e-book used in the cognitive domain, the effect in terms of technology, the effect in terms of skill and the effect in the emotional area. The students stated that the interactive e-book provides $17.8 \%$ better understanding and $11.6 \%$ often better learning. At this point, the sample of student interviews is as follows: "I did not understand the blood groups. Those experiments were there to differentiate blood groups. I got it with it. It had a lot of impact on my understanding." (SA8). In the opinion survey conducted, students showed that $6.2 \%$ of them thinks they provide visuals and $5.4 \%$ of them use the website as benefits. During the interviews, SC4 said, "In fact, we did not see such very visual things out of the book last year. There are more visual videos in what you showed this year. It 
had a beneficial effect on me.". In addition, in the opinion survey, it was stated by the students that the material enables to establish a relationship between the subjects $8.5 \%$ and $3.1 \%$ is more fun. At this point, SA1 said, "It had an impact on the relationship between the subjects. For example, in circulation, blood goes to the lungs, and the respiratory system and carbon dioxide come out of the lungs. I came to my mind while watching the animation on the subject." In addition, different opinions were expressed in the interviews that it contributed to loving science lessons. In this regard, SB3 "I did not like last year, but this year I got used to it, I love science lesson." They expressed their opinion. The opinions about the activities / animations liked by the students in the opinion survey are given in Table 4.

Table 4

Opinions on Activities / Animations Most Admired by Students

\begin{tabular}{llll}
\hline Code & f & $\%$ & Student Expressions \\
\hline The structure of the heart & 5 & 10.6 & "The one we watched about the heart, explaining the \\
Circulation & 5 & 10.6 & structure of the heart." (SA1) \\
Respiratory & 5 & 10.6 & "What I like the most is blood groups, which blood group we \\
3 d animations & 5 & 10.6 & were putting, matching. Matching is good, you do it yourself, \\
Blood circulation & 4 & 8.5 & there is no difficulty." (SA3) \\
All & 3 & 6.4 & "Three-dimensional ones. For example, while telling the \\
Blood cells & 3 & 6.4 & veins, it enters the vein, and I like it because the blood \\
Cell & 2 & 4.3 & circulating in it is dirty or not." (SB1) \\
Interview with the doctor & 2 & 4.3 & "Blood circulation, big and small circulation. Because I \\
Blood group determination test & 2 & 4.3 & couldn't quite understand, thanks to those animations, I \\
Alveoli & 2 & 4.3 & could understand. More has happened, there was \\
Circulation and breathing & 2 & 4.3 & explanatory narration." (SC3) \\
Animated concept cartoon & 2 & 4.3 & "I like the speeches, the children talk. If someone has more \\
Bone / skeleton & 2 & 4.3 & ideas, someone bigger, we may not care more about it. But \\
Experiments & 1 & 2.1 & it gets more attention when it comes to animation like our \\
Drag and drop animations & 1 & 2.1 & age. It allowed us to put ourselves in their shoes." (SC4) \\
Muscles & 1 & 2.1 &
\end{tabular}

As seen in Table 4, 10.6\% of the students who filled the opinion survey liked the animation related to the structure of the heart, $10.6 \%$ liked all animations in the circulatory system, $10.6 \%$ all animations in the respiratory system and $10.6 \%$ three dimensional animations. Data similar to these results were obtained in student interviews. In the student interviews, it was understood that the blood circulation (large and small blood circulation), animated concept cartoons, blood cells, bone, cell, structure of the heart and three-dimensional animations were liked. In the opinion survey applied, 54 of the students stated that there was no activity or animation they did not like throughout the unit. Only two students stated that there were parts they did not like. In the interviews, all 25 students stated that there was no activity they did not like. However, 
in the interviews, the opinions of the students in the parts that they consider missing while processing the systems unit in our body are given in Table 5.

Table 5

Students' Opinions Regarding the Missing Sections While Processing the Unit

\begin{tabular}{llll}
\hline Code & & f & $\mathbf{\%}$ \\
\hline None & & 20 & 80.0 \\
\hline Partially & Sound should be added to silent animations & 2 & 8.0 \\
& It should be a sentence instead of words & 1 & 4.0 \\
& Test should be added at the end of the subject & 1 & 4.0 \\
& & 1 & 4.0 \\
\hline Total & Lymph circulation should be added & 25 & 100.0 \\
\hline
\end{tabular}

As can be seen in Table 5, the students stated that $80.0 \%$ is not a place they see missing throughout the process. The opinion of SA3 regarding this situation is as follows: "No, all is well. We do the experiments. Animations are good, there is no missing animations." In addition, five students emphasized some shortcomings. Students stated that $8.0 \%$ of them should add sound to silent animations and $4.0 \%$ of them should say sentences instead of words. SC8 commented, "There were some quiet places, it would be better if someone narrated. Other than that, I think everything was ok, there was nothing missing."

\section{Findings Regarding Teachers' Opinions About Interactive E-Books}

Teacher A said that the interactive e-book prepared in the systems unit of the science course in our body is very useful with the statement of "It was very useful. They were all compiled and collected. So, we did not have to research from different places. It was all in one. It was very easy to use. There are all the instructions and stuff there, respectively. There was no problem." Similarly, teacher C stated his positive opinions as "Now, the website is prepared very well, the topics are well explained, we did not encounter any problems ...". On the other hand, teacher B said: "The website was beautiful and could be improved further. I can say that, but having such websites is awesome, visually." While expressing his positive opinion, he also stated that the website should be improved. In this context, it can be said that the interactive e-book is liked by the teachers for reasons such as combination of subjects, instructions, visuals.

In interviews, teachers were asked if they wanted similar websites to be prepared or not. In this regard, all three teachers stated the idea that similar websites should be prepared. The reason 
for this situation, teacher A said, "Yes, I have talked to you before. I think it will be very useful especially for the students who are preparing for the exam. Because there are very abstract concepts in that class... We draw our dreams, but it is better when there is animation. Our drawing is only two-dimensional. It gets more permanent in animation.”. Teacher B supported that idea by saying "Visualization is a beautiful thing. The more visual is available, the better it is for us." It was understood that teachers wanted websites to be prepared for other units for reasons such as embodying abstract concepts, having animations and images, and providing permanent learning.

Teachers stated that interactive e-book has many positive effects on students. Teacher A said, "The students were more active, they actively participated in the lesson... Their attention was always focused on science lesson. They very much enjoyed group work, they loved those drag and drop animations. We ultimately did group work and asked for products. We wanted to study poetry and write stories. We had skeleton competition with skeleton. It is always marketing. Of course, this situation has increased entrepreneurial spirits... Or, in the exchange of materials, the increase of tolerance to each other is also very important socially..." when expressing his/her views on its contributions to the students. The B teacher said, “... We ask the student about the location of the heart, it is between the two lungs. The child does not know what the lung is and where it is lest seeing it. First you will show the lung, you will show to which side the heart between the lungs tend to be, a phenomenon will occur in the child's head. You say that the rib cage bones protect the lung, protect the heart, and when you visually show it, it fits more into the child's mind, but if else it just stays in the air." expressing the importance to conceptual understanding with his statements. In this context, teachers stated that the interactive e-book improves the students' conceptual understanding, group work, entrepreneurship skills, interest in the lesson, and skills associated with daily life.

In the interviews, teachers stated that the interactive whiteboard is beneficial and has a positive effect on the students. Teacher B commented, "The use of interactive whiteboards is fine, I wish it had been set up before. So, I have nothing about it, technology is always beautiful. It's a great event, I love using it." In interviews, teachers were asked questions of inquiry. Teacher A said, expressing the importance of inquiry questions, "We have been teaching the lessons according to $5 \mathrm{E}$ theory before. It looks like the 5E system, I'm very happy with it. I think it provides motivation first. The student says "aha" or something, which makes her curious throughout the lesson. In the end, the same question comes up again and getting the answers 
makes us very happy. We get feedback. For example, there are answers that are not from daily life at first, wrong answers. But then they give much more realistic answers."

The teachers stated that in the interactive e-book used, there was no place they saw missing. However, a teacher states that it is beautiful, but some additions can be made. Teacher $\mathrm{C}$ expressed his/her positive opinions on this issue: "I have not seen much missing; you are prepared very well. We have benefited quite a lot." stating, B teacher: "How can something be done; we started from the cell or at the very beginning, we can make the cell interactive. We can make the two larger cells interactive. When you touch it, it says, 'I am the nucleus of the cell' and introduces itself. The other introduces itself, the other introduces itself or misrepresents it, the student tries to find it in the question and answer part. Throughout the unit, teachers $\mathrm{B}$ and $\mathrm{C}$ stated that the activities and animations were very good. Teacher A also stated that the e-book is very good and explained with examples as follows: "The blood group, circulation chart that I like the most. Actually, it was all very nice. We made a skeleton and had a lot of fun doing it. Then the completion with animation, the ones that drag. There were matching exercises in the organelles, it was very good. They liked all of them and also your video with that doctor from the beginning ... They were very surprised when the children watched your interview with the doctor at that moment. It was very effective for the students to watch by saying 'Ooo is our teacher'. But one-to-one doctor's presentation and speech there. Also, it was a speech appropriate for their level. The doctor speaks, but it doesn't match the level of our class. It's always Latin, it's repulsive. In other words, it was described very well in accordance with their curriculum." In addition, all three teachers stated that they could not distinguish the most liked feature throughout the interactive e-book, and that it was good as a whole. However, teacher A opened an extra parenthesis to the research questions and said the following sentences: "The questions in the introduction are very well-thought-out questions, like onion-hair analogy, how the drugs circulate in our body. Where did I like the most, questions in the introduction. Because it was a lot of questions in life that would have made me wonder why I hadn't thought of it before." In addition, teachers made some suggestions for interactive e-books. Teacher B said, "A little more can be corrected. The sound system could be better." addressing the lack of sound. Teacher A said, "Video support can be a little more. We watched the heart in three dimensions, video support could be like that... Or even direct link can be directed." and referred to three-dimensional animations. In addition, the teachers were lastly consulted about what could be added to the website and good suggestions were received from the teachers. Teacher A expressed his/her thoughts as: "Just like this, the website 
can be prepared. In addition, poems and photographs made by students can be added. Sometimes maybe there can be a forum about it ... Or teachers can add the material they find there. You may evaluate it and take it. Or it could be a forum for teachers, where we have difficulties or where we like it to be discussed, something like that.” Teacher B said, “... At the end of these websites, entertaining games can make children understand the achievements better. And I think they should be in a place where every student can reach them."

\section{Discussion, Conclusion and Suggestions}

In the study, students stated that it is nice, good and fun to process the systems unit in our body via interactive e-book. Similar practices in the literature have been reported to be beneficial, motivating and positively effective (Eristi et al., 2013; Ourania, Symenon, Ioannis, George \& Spyridoula, 2014). The main reason for this situation is thought to be due to the fact that the material contains multimedia objects and interaction. Interactive learning can already increase the motivation and interest of learning and takes the teaching activity from teacher-centered to student-centered learning (Chen \& Chen, 2011). In parallel with this situation, the lessons that are given as student-centered become more fun. In addition, students stated that the interactive e-book provides a better understanding, reinforces what is learned and helps the process of teaching the course. Similarly, in the study conducted by O'Mahony (2014) in the literature, it was understood that some widgets provided participants to remember better because of their superior presentation styles and interaction features. The interactive electronic book that can be learned from Lego simple power machine sets has been determined to make learning easier and faster than the traditional book (Shih, Chen, Cheng, Chen \& Chen, 2013). It is thought that there are positive effects on students' learning in parallel with the variety of interactive e-books that will appeal to many senses. In the study, students stated that among the benefits of the material is that it provides visuals, enables them to use the website, and makes it more fun. In the study carried out by Varol, Özer, and Türel (2014), prospective teachers stated sound, visual, video, animation, content, originality, remarkable elements, page design, interaction, evaluation and motivation elements among the powerful features related to interactive e-books. In addition, it has been understood that web / technology-based inquiry-based learning in science education is fun (Sing \& Chew, 2009, Türkmen, 2009) and children between the ages of seven and nine find the interactive e-book fun and impressive (Zhang-Kennedy \& Chiasson, 2016). In this context, it can be said that the interactive e-book contains visual elements and contains the interaction feature, and it is found to be fun by the students. 
In the study, the students stated that the interactive board is beautiful in parallel with the interaction feature and provides a better understanding of the subject. In the studies in the literature, the participants stated that the use of interactive boards in science contributes to their understanding of the subject (Akbaş \& Pektaş, 2011; Emron \& Dhindsa, 2010; Yang, Wang \& Kao, 2012). In addition, the participants stated that the lessons became more fun / enjoyable thanks to interactive board applications (Hall \& Higgins, 2005; Kırbağ Zengin, Kırılmazkaya \& Keçeci, 2012; Sarı \& Güven, 2013) and interesting (Hennessy, Deaney, Ruthven \& Winterbottom, 2007). When we look in general, interactive boards attract attention due to reasons such as having the latest features of technology, enabling interaction environment and it is easier for students to understand the subject. In the study, sixth grade students expressed their opinions about the animations that they provide better understanding, that they are more real, beautiful and fun. In studies conducted in science education in the literature, animations have been found to increase success / learning (Daşdemir, Uzoğlu \& Cengiz, 2012; Kwasu, Yalams \& Ema, 2016; O’Mahony, 2014). In addition, Yakışan, Yel and Mutlu (2013) stated that students in biology teaching liked the teaching with animations and learned that they learned the subjects and events they could not understand more easily because they were able to animate them better through animations. In this context, as stated by the students in the study, it is understood that animations have an interesting aspect in parallel with both students' understanding and visual and animation features. It was stated that the animated concept cartoons used in the study were beautiful and good by the students, they helped to understand the truth / wrong, they were helpful and helpful to understand. It has been understood in the literature that animated concept cartoons increase success / understanding (Aydin, 2015; Dalacosta, Kamariotaki-Paparrigopoulou, Palyvos \& Spyrellis, 2009), students enjoy (Aydın, 2015) and think more comprehensively (Başarmak \& Mahiroğlu, 2015). As it is known, concept cartoons are loved by students and it has been determined that they have positive effects on their learning. In addition to this, it can be said that transferring and animating the concept cartoons to the computer environment increases these effects in parallel with the results obtained from both the study and the studies in the literature.

In the study, the students stated that in the interviews, different from the opinion survey, the interactive e-book contributed to the love of science lesson. In the literature, it can be stated that students using interactive books in biology lessons have higher motivation (Baughman et al., 2013), that is, ibooks / interactive e-books increase student motivation (Al-Qassabi \& Al- 
Samarraie, 2013; O’Mahony, 2014). In addition, it is determined that inquiry based learning based on the material improves students' attitudes, motivations and interests in science positively (Gibson \& Chase, 2002; Tatar \& Kuru, 2009; Wu, Wu, Shih \& Wu, 2014). It can be said that with the application made in this context, students' views against science, which is perceived as a difficult lesson, have changed and they started to love science more. It is thought that this situation has developed in parallel with the students' liking of the subject and the understanding of the lesson.

In the study, animation related to the structure of the heart, all animations in the circulatory system, all animations in the respiratory system, animated concept cartoons and threedimensional animations are among the most liked activities / animations. In fact, it can be said that students like animation, activity and multimedia objects in almost all subjects. The fact that all of the students stated that there is no activity or animation they dislike is another support for this situation. Similarly, in the interviews, the majority of students stated that there is no place that they see missing when processing the systems unit in our body. Only five students dwelled on some shortcomings such as adding sounds to silent animations and having sentences instead of words. As a result of the study carried out in this context, it can be said that the students liked the interactive e-book and enjoyed the activities throughout the process.

As a result of the study, teachers stated that the interactive e-book prepared in the systems unit in our body is useful. The teachers stated that the interactive e-book is useful because of its features such as being compact, planned, with lesson duration and time, easy to use, clear instructions, and visuality. Similarly, in the study carried out by Baughman et al. (2013), teachers stated that the amount of material and the speed of the program's progress in interactive books in the biology lesson were correct, the program was easy to implement, and it was a valuable teaching resource, improving student participation and understanding of students. Özöğüt Erorta and Kayabaş (2015) stated that interactive e-books are always ready for the use of learners in every environment. In this context, it can be stated that the interactive e-book was liked by the teachers for reasons such as being organized and planned and easy to use. In this context, it is thought that interactive e-books contain many features and offer them collectively are positively received by teachers.

In the study, teachers stated that similar websites should be prepared due to features such as embodying abstract concepts and visualization in parallel with animations in the interactive e- 
book. This may be due to the increased interest in interactive materials, interactive e-books, ebooks in parallel with the development of technology (Brajković, 2014). When we look at the benefits of the interactive e-book applied, the teachers stated that the material improved its features such as students' conceptual understanding, group work, entrepreneurship skills, interest in the lesson, and skills associated with daily life. In the literature, science teacher candidates state that technology-based inquiry-based learning enables them to create studentcentered, motivating and participatory learning opportunities (Hakverdi-Can \& Sönmez, 2012). In addition, they stated that they preferred the pre-service teachers of information technologies for reasons such as interactive books, written text, entertaining, making learning more meaningful and ensuring their active participation in the process (Özer \& Türel, 2015). In this context, the results obtained from these studies support our results. As a result, it is thought that teachers prefer a material that will improve students' cognitive characteristics such as success, understanding, and skills such as group work and entrepreneurship.

As a result of the study, the teachers stated that the interactive whiteboard is beneficial and has positive effects on the students. In the literature, teachers stated that the interactive board has a positive effect on the learning environment (Erduran \& Tataroğlu, 2009; Sweeney, 2013) and is useful in accessing information (Gadbois \& Haverstock, 2012). As stated by the students, this situation can be said to be parallel to the latest features of technology. However, in the study conducted, teachers stated that the inquiry questions were good, that they provided motivation first, contributed to learning, and were useful in establishing a relationship with daily life. In this context, it can be said that the teachers liked the research-inquiry questions. In fact, as Songer, Lee \& Kam (2002) stated in their study, teachers find research and inquiry pedagogy both convenient and challenging. Because it can be said that research-based learning is one of the most difficult parts in terms of both practice and preparation. Similarly, in the study of Bayram (2015), preservice teachers stated that they were trying to create a problem area that reflects the real world, especially about daily life, while designing science activities based on guided inquiry. In this context, preparation of research questions is an important point, but it is thought that this point should be given importance while developing the material.

In the study, teachers stated that they did not have a place in the interactive e-book used, that they liked the material and that the prepared material (animation, activity) was beautiful. In the first experiences of WebQuest, science pre-service teachers stated that they are a valuable teaching tool despite the limitations and disadvantages, and they will use it as a teaching- 
learning tool (Hakverdi-Can \& Sönmez, 2012). In addition, in another study, most of the participants stated that they have positive opinions about the use of e-books in science classrooms and are willing to overcome the difficulties they face (Luaran, Rom, Nadzri \& Jain, 2016). In addition, in some studies in the literature (Choiriyah, 2015; Tania \& Fadiawati, 2015; Wirawan \& Unesa, 2012), interactive e-book has been developed and it is concluded that it is appropriate. In this context, in our study, it was understood that the interactive e-book developed was suitable and liked by the teachers.

In the study, teachers stated that there were some deficiencies in the interactive e-book and made some suggestions to solve them. Teachers made interactive e-book developer suggestions that the audio system can be edited, the number of videos can be increased, three-dimensional animations can be linked, student materials can be added to the website later, entertaining games can be added, and the website is accessible to every student. Songer et al. (2002) stated that the obstacles encountered in the study were the availability of insufficient space and materials in a few cases, insufficient time, low content knowledge among teachers, large class capacities, limited teaching freedoms and unreliable internet connection. However, given the difficulties of the interactive e-book development process; it is usual to have such minor disruptions. Similarly, Bozkurt \& Bozkaya (2013a) interactive e-book design process prepared as a learning material; It states that it is a comprehensive process in which different designs, expertise and disciplines are put to work. In this context, it is clear that interactive e-books to be prepared interdisciplinary will make great contributions to the field.

As a result, the students stated that they liked the features such as interactive whiteboard, animations, research questions, interactive objects, and website in the interactive e-book material. In this way, they stated that the lessons became more beautiful and fun, they understood the subject better, they could associate it with daily life, and they learned it permanently. In fact, it is expected that students will learn better in line with the features they have stated in the material. When we look at the general results obtained from the teachers, it was understood that the interactive e-book was liked and found useful by the teachers. It has been stated that the main reason for this situation is that it is a regular, systematic and progressive system parallel to the gains. Although there are many materials related to science subjects in the literature, they are generally scattered. When teachers want to use these materials, they need to research for a long time before starting the topic or which one they will use in the process. In this case, teachers have great responsibilities and it is very easy to use 
these materials effectively. It is thought that this situation is corrected with the material developed and used in this study and it provides convenience for teachers. In addition, teachers stated that the interactive e-book embodies the abstract concepts on the subjects for students and provides positive understanding as well as understanding. It is thought that this situation is caused by situations such as method, interactive board and multimedia objects in the material. In this process, although the teachers liked the interactive e-book, they made some suggestions. In particular, they made suggestions such as increasing the sound feature of the animations, adding three-dimensional animations and increasing the number of videos. These suggestions are considered to be good suggestions for the development of the interactive e-book, and making these arrangements is important for the development of the interactive e-book.

\section{Suggestions}

Considering that the interactive e-book developed in the study has many positive effects on students, it is considered that interactive e-books for other units in science education should be developed and introduced to teachers. It is thought that the focus should be especially on the subjects where the students have more problems or on subjects that contain alternative concepts. In the study, it is seen that in the animations in the interactive e-book (website), the process related to an event or concept is processed with sound or silent. As the students and teachers stated in the interviews, it is thought that some animations should be added to the sound, or a description of what happened in the animation should be added to a page after the animations. Also, in terms of animations, it can be suggested that some animations in the literature can be linked to three-dimensional animations, in particular.

\section{Statements on ethics and conflict of interest}

Research permit numbered 86896125-605.01-E.9113990 was obtained within the scope of the study. Ethical issues were considered throughout the study. There is no conflict of interest in this study. 


\section{References}

Altınbaş Akbaş, O., \& Pektaş, H. (2011). The effects of using an interactive whiteboard on the academic achievement of university students. Asia-Pacific Forum on Science Learning and Teaching, 12(2), 1-19.

Alfrijat, A. M., Al-Msie'deen, R., \& Alhalhouli, Z. T. (2010). Interactive book as e-training material for the eduwave system in Jordan. Advances in Computer Science and Engineering, 5(1), 97-104.

Al-Qassabi, H., \& Al-Samarraie, H. (2013). Applying Gagne's nine events in the design of an interactive ebook to learn 3D animation. Advances in Computing, 3(3), 60-72.

Arslan, A. S. (2014). Folk culture and enriched books: Evaluation of digital tools and enrichment tools with examples "E-Anagnosis". Cankiri Karatekin University Journal of Faculty of Letters, 4(4), 87.

Aydın, G. (2015). The effects of computer-aided concept cartoons and outdoor science activities on light pollution. International Electronic Journal of Elementary Education, 7(2), 143-156.

Barate, A., Ludovico, L. A., \& Mangione, G. R. (2014, July). A new paradigm for music education: Creating active e-books through the IEEE 1599 Standard. Advanced Learning Technologies (ICALT), 2014 IEEE 14th International Conference, Athens, Greece.

Başarmak, U., \& Mahiroğlu, A. (2015). Student opinions on the animated cartoons used in online learning environment. International Journal of Eurasia Social Sciences, 6(19), 234-253.

Baughman, M., Ehmann, M., \& Vilcheck, A. (2013). The effects of iBooks biology on student science achievement and motivation. Always Learning, Pearson.

Bayram, Z. (2015). Investigating difficulties that preservice science teachers encounter while designing guided inquiry activities. Hacettepe University Journal of Education, 30(2), $15-29$.

Belveal, L. K. (2016). No Nä Hale: Developing an interactive iBook to promote learning for the Hawaiian lowmersion elementary classroom. 
https://scholarspace.manoa.hawaii.edu/bitstream/10125/40216/2/TCCPaper2.pdf adresinden 21.09.2016 tarihinde edinilmiştir.

Bozkurt, A. (2013). Defining evaluation criteria for interactive e-books for open and distance learning (Unpublished Master Thesis). Anadolu University, Eskişehir, Turkey.

Bozkurt, A., \& Bozkaya, M. (2013a). Interactive e-book preparation steps as a learning material. Journl of Educational Policy Analysis, 2(2), 8-20.

Bozkurt, A., \& Bozkaya, M. (2013b, Ocak). Interactive e-book: Yesterday, today and tomorrow. Academic Informatics Conference, Antalya, 375-381.

Brajković, M. (2014). Tools and methodologies for developing interactive electronic books (Doctoral dissertation). Grafički fakultet, Sveučilište u Zagrebu.

Campbell, C., \& Martin, D. (2010). Interactive whiteboards and the first year experience: Integrating IWBs into pre-service teacher education. Australian Journal of Teacher Education, 35(6), 68-75.

Chen, C. C., \& Chen, C. M. (2011, July). The application of interactive media display technology in environmental science learning. HCI International 2011, Japan.

Choi, J., Lee, Y., \& Kim, K. (2014). An HTML5-based interactive e-book reader. International Journal of Software Engineering and Its Applications, 8(2), 67- 74.

Choiriyah, N. (2015). Developing of interactive e-book media on subject matter of chemicals in daily life for high school deaf student. UNESA Journal of Chemical Education, 4(1), 119-125.

Colburn, A. (2000). An inquiry primer. Science scope, 23(6), 42-44.

Colburn, A. (2004). Inquiring scientists want to know. Educational Leadership, 62, 63-67.

Çepni, S. (2018). Introduction to research and project studies. Trabzon: Celepler Printing.

Çepni, S., \& Çil, E. (2009). Science and technology program (diagnostics, planning, implementation and association with SBS) primary and primary education manual. Ankara: PegemA Publishing.

Dalacosta, K., Kamariotaki-Paparrigopoulou, M., Palyvos, J. A., \& Spyrellis, N. (2009). Multimedia application with animated cartoons for teaching science in elementary education. Computers \& Education, 52(4), 741-748. 
Daşdemir, İ., Uzoğlu, M., \& Cengiz, E. (2012). The effect of use of animations in unit of body systems on the academic achievements of the 7th students, retention of the knowledge learned, and the scientific process skills. Trakya University Journal of Education, 2(2), 54-62.

Doğan, D., Murat, Ç., \& Seferoğlu, S. S. (2016). “One laptop per child” projects and FATIH project: A comparative examination. SDU International Journal of Educational Studies, 3(1) 1-26.

Emron, S., \& Dhindsa, H. S. (2010). Integration of interactive whiteboard technology to improve secondary science teaching and learning. International Journal of Research and Engineering (IJRE), 28, 1-24.

Erdoğdu, E. (2016). Interactive ebooks in the context of open and distance learning: Interaction, technology, production size and examples. Journal of Open Education Practices and Research, 2(3), 88-114.

Erduran, A., \& Tataroğlu, B. (2009, May). Comparison of science and mathematics teacher views regarding the use of smart board in education. $9^{\text {th }}$ International Educational Technology Conference, Ankara, Turkey.

Erişti, S. D., Uluuysal, B., \& Dindar, M. (2013). Designing an interactive learning environment based on theories of visual perception and students' views about the software. Anadolu Journal of Educational Sciences International, 3(1), 47-66.

Gadbois, S. A., \& Haverstock, N. (2012). Middle years science teachers voice their first experiences with interactive whiteboard technology. Canadian Journal of Science, Mathematics and Technology Education, 12(1), 121-135.

Garrison, D. R., \& Cleveland-Innes, M. (2005). Facilitating cognitive presence in online learning: Interaction is not enough. The American Journal of Distance Education, 19(3), 133-148.

Gasouka, M., Kapaniaris, A., Arvanitidou, Z., Foulidi, X., \& Raptou, E. (2013, March). Folk culture and digital enriched books: The case study of the digital enriched tool " $e$ anagnosis". $7^{\text {th }}$ International Technology, Education and Development Conference, Valencia, Spain.

Gebya Oktammeria, H., \& Novita, D. (2012). The assessment of student's mind mapping result on limited trial towards bilingual interactive e-book media through mind mapping 
strategy on chemical bonding matter for SMA RSBI. Unesa Journal of Chemical Education, 1(1), 115-123.

Gibson, H. L., \& Chase, C. (2002). Longitudinal impact of an inquiry-based science program on middle school students' attitudes toward science. Science Education, 86(5), 693-705.

Gümüş, S., Güler, E., Güler, C., \& Erorta, Ö. (2012, November). Interactive ebook design tools for mobile devices. XVII. Internet Conference in Turkey, Eskişehir, Turkey.

Hakkari, F., Yeloğlu, T., Tüysüz, C., \& İlhan, N. (2017). Development of an instructional material for an enriched book relating to "interactions between chemical types" unit in the ninth grade chemistry curriculum and investigation its effects. Education and Science, 42(192), 327-348.

Hakverdi-Can, M., \& Sönmez, D. (2012). Learning how to design a technology supported inquiry-based learning environment. Science Education International, 23(4), 338-352.

Hall, I., \& Higgins, S. (2005). Primary school students' perceptions of interactive whiteboards. Journal of Computer Assisted Learning, 21(2), 102-117.

Hennessy, S., Deaney, R., Ruthven, K., \& Winterbottom, M. (2007). Pedagogical strategies for using the interactive whiteboard to foster learner participation in school science. Learning, Media and Technology, 32(3), 283-301.

Kara, M., \& Keş, Y. (2016). Interactive e-book as a learning tool. Art-e Art Journal, 9(17), 189209.

Karakuş, U. (2006). The effect of experimental method atstudents? Success level while teaching climate subject in geography (Unpublished PhD Thesis). Gazi University, Ankara.

Karakuyu, Y., Bilgin, İ., \& Sürücü, A. (2013). Effect of inquiry based learning approaches on university students' academic achievement and science process skills in general physics laboratory course. Mustafa Kemal University Journal of Social Sciences Institute, 10(21), 237-250.

Khan, B. H. (Ed.). (1997). Web-based instruction. New Jersey: Educational Technology Publications.

Kırbağ Zengin, F., Kırılmazkaya, G., \& Keçeci, G. (2012). Elemantary students use of smart board the effect of achievement and attitude in science and technology course. $E$ Journal of New World Sciences Academy, 7(2), 526-537. 
Kızılaslan, A., Sözbilir, M., \& Yaşar, M. D. (2012). Inquiry based teaching in Turkey: A content analysis of research reports. International Journal of Environmental and Science Education, 7(4), 599-617.

Kwasu, I. A., Yalams, S. M., \& Ema, E. (2016). Using design \& animation concepts to produce animated instructional resources that can facilitate open distance learning in science and technology education. Journal of Education and Practice, 7(17), 166-170.

Laili, M. I., \& Novita, D. (2014). The assessment result of mind mapping in implementation of bilingual interactive e-book media through mind mapping strategy on chemical bonding. UNESA Journal of Chemical Education, 3(1), 83-87.

Llewellyn, D. (2014). Inquiry within: Implementing inquiry- based science standarts. USA: Corwinn Pres, Inc. A Sage Publications Company.

Luaran, J. E., Rom, K. B. M., Nadzri, F. A., \& Jain, J. (2016). E-book usage in teaching science: The perspectives of science teachers in secondary schools in Selangor. Malaysian Journal of Distance Education, 18(1), 13-27.

Mayer, R. E., \& Moreno, R. (2002). Animation as an aid to multimedia learning. Educational Psychology Review, 14(1), 87-99.

Ministry of National Education (MoNE) (2010). A project to increase technology opportunities in education, to improve technology (FATIH). Ankara: General Directorate of Innovation and Educational Technologies.

Nivalainen, V., Asikainen, M. A., \& Hirvonen, P. E. (2013). Open guided inquiry laboratory in physics teacher education. Journal of Science Teacher Education, 24(3), 449-474.

O'Mahony, N. (2014). Cognitive learning and motivation of first year secondary school students using an interactive and multimedia-enhanced e-book made with ibooks author. Irish Journal of Academic Practice, 3(1), 1-34.

Ourania, P., Symeon, R., Ioannis, P. George, S., \& Spyridoula, L. (2014, June). Inquiry based learning in primary education: a case study using mobile digital science lab. Thinking Assessment in Science and Mathematics - Science and Mathematics Education Conference, Dublin.

Önder, F., \& Silay, İ. (2016). The effect of enriched e-book supported laboratuary activities on pre-service teachers' attitudes towards computer-supported education. Journal of Abant Izzet Baysal University Faculty of Education, 16(3), 945-960. 
Özer, S., \& Türel, Y. K. (2015). ICT teacher candidates' metaphoric perceptions of e-book and interactive e-book. Turkish Online Journal of Qualitative Inquiry, 6(2), 1-23.

Özoğlu, Y., Kaysi, F., \& Özoğlu, F. (2014). Production epub standard curriculum course content for mobile devices. Journal of Research in Education and Teaching, 3(1), 196206.

Özöğüt Erorta, Ö., \& Kayabaş, İ. (2015, February). Anadolu university interactive e-Book project. Academic Informatics, Eskişehir, Turkey.

Phadung, M. (2015, December). Interactive e-book design and development to support literacy learning for language minority students. 2015 World Congress on Sustainable Technologies (WCST), London.

Sarı, U., \& Güven, G. B. (2013). The effect of interactive whiteboard supported inquirybased learning on achievement and motivation in physics and views of prospective teachers toward the instruction. Necatibey Faculty of Education Electronic Journal of Science and Mathematics Education, 7(2), 110-143.

Shih, B. Y., Chen, T. H., Cheng, M. H., Chen, C. Y., \& Chen, B. W. (2013). How to manipulate interactive E-book on learning natural catastrophe - an example of structural mechanics using power machine. Natural Hazards, 65(3), 1637-1652.

Sing, K. M., \& Chew, C. (2009, November). An inquiry approach in learning science with engaging web-based multimedia interactive resources. International Science Education Conference, Singapore.

Soga, T., Nakahara, T., Kawana, N., Fuse, I., \& Nakamura, Y. (2015, October). Interactive learning using e-books connected with moodle and development of sharing environments for teaching materials. E-Learn: World Conference on E-Learning in Corporate, Government, Healthcare, and Higher Education.

Songer, N. B., Lee, H. S., \& Kam, R. (2002). Technology-rich inquiry science in urban classrooms: What are the barriers to inquiry pedagogy? Journal of Research in Science Teaching, 39(2), 128-150.

Steininger, R., \& Lembens, A. (2012, September). Involving students in research on the use and construction of concept cartoons for chemistry classes. ESERA 2011 Conference, Science Learning and Citizenship, Lyon, France. 
Stephenson, P., \& Warwick, P. (2002). Using concept cartoons to support progression in students' understanding of light. Physics Education, 37(2), 135-141.

Sweeney, T. (2013). Understanding the use of interactive whiteboards in primary science. Australasian Journal of Educational Technology, 29(2), 217-232.

Tania, L., \& Fadiawati, N. (2015). Development of interactive e-book based on chemical representation refer to curriculum 2013. Jurnal Pendidikan IPA Indonesia, 4(2), 164169.

Tatar, N., \& Kuru, M. (2009). Inquiry- based learning approach versus descriptive methods: effects on elementary students' attitudes towards science. Pamukkale University journal of Education, 25, 153-165.

TUSIAD (2017). 2023 towards STEM requirement in Turkey. It was obtained from http://tusiad.org/tr/yayinlar/raporlar/item/9735-2023-e-dog-ru-tu-rkiye-de-stemgeneration on 26.03.2018.

Türkmen, H. (2009). An effect of technology based inquiry approach on the learning of" Earth, Sun, \& Moon" subject. Asia-Pacific Forum on Science Learning \& Teaching, 10(1), 120.

Varol, F., Özer, S., \& Türel, Y. K. (2014). ARCS motivasyon modeline yönelik tasarlanan zkitaplara ilişkin görüşler. Journal of Instructional Technologies \& Teacher Education, 3(3), 1-8.

Wirawan, I., \& Unesa, J. K. F. (2012). The development of international standard curriculum interactive chemistry e-book on acids, bases and salts topic at grade VII OF SMP. UNESA Journal of Chemical Education, 1(1), 230-234.

Wu, P. L., Wu, L. C., Shih, W. L., \& Wu, M. L. (2014). A comparison study on the influence of implementing inquiry-based instruction on science learning motivation and interest. Asian Journal of Management Sciences \& Education, 3(3), 74-82.

Yakışan, M., Yel, M., \& Mutlu, M. (2013). Student's view for using computer animations on teaching biology. Turkish Journal of Education, 2(3), 30-39.

Yang, K. T., Wang, T. H., \& Kao, Y. C. (2012). How an interactive whiteboard impacts a traditional classroom. Education as Change, 16(2), 313-332. 
Zhang-Kennedy, L., \& Chiasson, S. (2016, June). Teaching with an interactive e-book to improve children's online privacy knowledge. $15^{\text {th }}$ International Conference on Interaction Design and Children, Manchester, United Kingdom. 